\title{
CAPITAL INFLOWS, FINANCIAL REPRESSION AND MACROECONOMIC POLICY IN INDIA SINCE THE REFORMS
}

\author{
Partha Sen \\ Email: partha@econdse.org \\ Delhi School of Economics \\ University of Delhi
}

Working Paper No. 157 


\title{
CAPITAL INFLOWS, FINANCIAL REPRESSION AND MACROECONOMIC POLICY IN INDIA SINCE THE REFORMS *
}

\author{
Partha Sen \\ Department of Economics \\ Delhi School of Economics \\ Delhi 110007 \\ India
}

partha@econdse.org

\begin{abstract}
Since the early 1990s the Indian economy has seen a considerable relaxation of controls, as a consequence of which it has witnessed unprecedented growth. This is especially remarkable in the external sector. In this paper I evaluate the progress made on the macroeconomic front and address the possibility of opening up the capital account of the balance of payments. I show that given the weakness in the financial sector and the government finances, it may be dangerous to speed up the process of opening up the capital account further.
\end{abstract}

Key words: Economic liberalization, financial repression, capital account convertibility

JEL classification: E58, F21, F32, F43

I am grateful to the Centre for Development Economics for providing research support and to Vineeta Sharma for research assistance. I have benefited from discussion on these issues with Partha Chatterjee, Errol D'Souza, Nira Goyal, Vijay Joshi, Kenneth Kletzer and Urjit Patel. The comments by a referee and Andrew Glyn has, hopefully, improved the quality of the paper. 


\section{Introduction}

Soon after its independence from Britain in 1947, India embarked on a policy of growth based on import-substitution, with the state sector positioning itself on the "commanding heights" of the economy. Economic and political populism (and in its wake, financial repression) came a few years later. In the last fifteen years there has been a reversal of these policies (though not in full measure), and the Indian economy has opened up considerably to international trade and capital flows.

It is interesting to note that both the start of the previous episode of economic populism and the recent period of liberalisation (i.e., the end of populism), can be traced to macroeconomic crises that preceded them. The first macroeconomic crisis occurred in the mid-1960s when following a string of crop failures due to inadequate rainfall, the Indian government was forced to devalue the currency. In 1969, the then Prime Minister, Indira Gandhi, adopted a populist stance that marked a break with the tradition of conservatism in financial matters. Fourteen commercial banks, with assets in excess of Rs. 500 million, were nationalised. Another six, whose assets exceeded Rs. 2 billion, were added in 1980.

The legacy of populism was a large financial sector dominated by government-owned banks. The inefficiently run public sector manufacturing units making losses perpetually and large subsidies to politically-favoured lobbies, meant that the government started running large deficits and hence had a voracious appetite for funds. Recourse was, however, not taken to monetisation in a big way. Borrowing, and the consequent high interest payments, pointed towards using the banks to service the needs of the government rather than allowing them to engage in commercial lending. There were controls on interest rates (both borrowing and lending). Foreign exchange use was restricted and even the raising of capital by the private sector firms needed government permission.

At the beginning of the 1990s, following another macroeconomic crisis, India jettisoned this almost half-a-century of import-substitution and a quarter century of financial repression. The question naturally arose as to whether it would follow the industrialisation strategy adopted by the East Asian economies. Economists, especially of a liberal persuasion, point to these countries as success stories of an outward-looking strategy, in contrast to the inward-looking import- substitution strategy which was deemed a failure.

Macroeconomic modelling for developing countries is not an easy task. There is a body of accepted macroeconomic tools for developed countries but developing countries are too disparate in their economic structures -- almost reminding one of Tolstoy's observation that all happy families were the same but all unhappy families were unhappy in different ways. A recent study on the Latin American experience sums this up nicely (Calvo and Talvi (2006, p.1)): "Unfortunately, false starts and painful crashes have not given rise to a solid academic literature comparable to the one dealing with problems in the North. 
Rather, the failure of a false start is quickly attributed to the skates used on the ice patch. Thus, for example, the Washington Consensus ignored the key role of high volatility of international capital markets."

Of course, as a consequence of the various macroeconomic crises in developing countries, some attention has been paid to the distinctive features of these economies. For instance, Mishkin (2004) lists the macroeconomic features of emerging market economies that make them different from those with developed capital markets: These are: "1) Weak fiscal institutions, 2) Weak financial institutions including government prudential regulation and supervision, 3) Low credibility of monetary institutions, 4) Currency substitution and liability dollarization; and 5)Vulnerability to sudden stops (of capital inflows)."1

Going back to the issue of an outward-looking industrialization strategy, it is important to realise that there were crucial difference among the countries in Asia that have successfully followed such a strategy. Japan and Korea had almost no foreign direct investment (FDI) flows, while others like Singapore, and later China, had these in ample quantities. The common policy conclusion that jumps out of these strategies is the almost mercantilist trade surpluses run by these countries and the absence of any portfolio flows, in the early stages of development. But, in sharp contradistinction to the fast growing economies in Asia, India liberalised both its current and capital account components of the balance of payments (the latter to non-debt inflows of all kinds with guaranteed repatriation). This in spite of evidence showing that those who opened their capital accounts to anything more than FDI quickly landed themselves in trouble as the Latin American experience (e.g., the Southern Cone experience of the early 1980s, the Mexican experience of the mid-nineties, or their more recent experience-the recent crisis is discussed in some detail in section 4 below) shows. Too much openness is, then, not so good. ${ }^{2}$

In this paper, I will analyse India's recent macroeconomic performance and suggest what a prudent policy stance might be. Lacking an acceptable structure, there is no unique "correct" policy stance. One has to try to be "sensible" in the light received economic wisdom. Unlike Latin America, there is no macroeconomic tradition in India-possibly because it has not been subject to recurring macroeconomic crises unlike Latin America. Another problem facing such an endeavour is that, unlike other countries, neither the

\footnotetext{
${ }^{1}$ Mishkin (2004) p.5. Of these, we shall see below that only the first and the second fit the Indian policy stance to date. Its monetary authority never resorted to monetization in a big way, so the third feature does not apply. And its capital account, so far, has not been sufficiently open for the fourth and the fifth points to apply.

2 Broner and Rigobon (2004) look at twenty-three developed and thirty-five emerging market economies and find that capital flows to the emerging market countries are 1.79 times more volatile than those to the developed countries, while the (left) skewness (that is, proneness to crises) is 1.5 times as high. In addition to "fundamentals," emerging market economies experience more contagion and persistence. Since their (annual) data goes back to 1965, it probably understates the volatility.
} 
Reserve Bank of India nor India's Ministry of Finance has a macroeconomic model that policy is based on. Periodically they do appoint "high-powered" committees but the quality of these reports leaves something to be desired. ${ }^{3}$

The rest of this paper consists of three sections. The next section provides the background to India's liberalisation experience and discusses, in some detail, the fiscal policy and the banking sector problems. These could prove to be potential sources of trouble as India mulls opening up the capital account. At the very least, the fact that these sectors are not exactly in the pink of health should lead to a more cautious approach when approaching the issue of a fully open capital account. The third section discusses the Indian experience with capital flows to date. The final section discusses what should be done in the light of the analysis of the previous two sections. Here I borrow heavily, but selectively, from the existing literature on the pros and cons of capital account convertibility.

\section{Economic Growth, Fiscal Policy and the Financial Sector}

Macroeconomic policy-making came into its own in India during the 1980s as government controls on economic activity were progressively removed. This was a period of relatively high growth accompanied by rising fiscal deficits. As in many other emerging markets, financial repression was used by the government to corner a high proportion of savings to meet its demand for funds. ${ }^{4}$ The banks were required to hold, in addition to the usual Cash Reserve Ratio (CRR), a certain percentage of their assets in the form of government securities, known as the Statutory Liquidity Ratio (SLR). Borrowing and lending rates were administered rather than market determined. A certain proportion of lending had to be directed towards the "priority" sectors-mainly agriculture and small-scale industry. Accounting standards were very lax-income was based on accrual rather than cash received. Unsurprisingly, therefore, at the beginning of the liberalisation of financial markets in the early 1990s, about 24 percent of advances were nonperforming and only about half of the state-owned banks made positive profits. In the primary market (until 1992), firms had to obtain permission from a body called the Controller of Capital Issues (set up immediately after independence in 1947), which decided the amount and the price of the primary issue. ${ }^{5}$

The second half of the 1980s was different from the preceding years since independence in that real exchange rate targeting was practiced with a view to improving the country's export performance. The real effective exchange rate was allowed to depreciate by 30 per cent between 1985-86 and 1989-90. This was brought about by a nominal depreciation of about 45 per cent over

\footnotetext{
3 I will give some examples below.

${ }^{4}$ Kletzer (2004, pp21-22) calculates implicit interest subsidy on public debt and seignorage at an average of 8.2 per cent of GDP over the period 1980-93.

5 See Sen (2001) for a further discussion of this period.
} 
the same period. If allowance is made for tax breaks and other subsidies to exporters, the real depreciation could be as high as 40 per cent. ${ }^{6}$

During this period exports rose at an annual rate of five percent and imports (which were also liberalised somewhat) at eight per cent. By 1990-91 the fiscal deficit had ballooned to 8.4 per cent of GDP and the current account deficit to 3.1 per cent of GDP. The Gulf War in 1990 showed how fragile the macroeconomic balance in India was at the time-the shock was temporary and at most amounted to one per cent of GDP--but caused a full-blown balance of payments crisis.

The government appointed two committees to examine ways to reduce financial repression. The first appointed by the Reserve Bank of India (RBI), India's central bank in 1985, known as the Chakravarty Committee, recommended market-related interest rates be paid on debt, and reductions in CRR and SLR, and the creation of a market for debt. The other committee, popularly known as the Narsimham Committee, was set up by the Government of India in 1991. It made recommendations to make the banking system more competitive and, more importantly, more transparent. To this end, it recommended that the SLR should be brought down to 25 percent (from 38.5 percent), the interest paid to banks on CRR should be increased, government-owned banks be allowed to raise equity from the capital markets, and the imposition of Basle (Basle I) norms with a CRAR of 8 percent. On the important issue of privatisation of government-owned banks, the Committee recommended that they be given autonomy rather than privatised since it believed that "issues of competitive efficiency and profitability were ownership neutral". Although it is not clear as to the exact reason, privatisation was seen as a move away from social sector responsibilities of the banking system.

\section{(See Table 1)}

The movement of some macroeconomic indicators since the early 1990s can be seen in Table 1. The growth rate of the economy is quite impressive (industrial growth has also been fairly robust) and inflation, in recent years at least, very reasonable. The current account of the balance of payments also does not give any cause for worry.

The improved performance of the financial sector, and in the macroeconomic scenario generally, in the years following the crisis of 1990 is due to the farreaching changes introduced by the government. It has, in the light of the recommendations made by the Chakravarty and Narsimham Committees, progressively relaxed interest rate ceilings, reduced the SLR requirements of banks, and actively encouraged a domestic market in government debt instrument. The entry of foreign banks and domestic private banks was

\footnotetext{
${ }^{6}$ See Joshi and Little (1994), Chapter 7 for an account of the macroeconomic developments in this period.
} 
encouraged. ${ }^{7}$ The product (though not the labour) market was freed of governmental regulations, the Securities and Exchange Board of India (SEBI) was set up in 1988 and given statutory powers in 1992. Screen-based trading was introduced in the stock market known in the past for its murky dealings. In the external sector, tariff rates were lowered, restrictions on foreign exchange transactions (on the current account) ${ }^{8}$ eased and foreign direct investment (FDI) liberalised. On capital inflows, it kept a lid on short-term (potentially volatile) flows but gave permission for full outflows associated with inflows (i.e. principal, interest, dividends, profits and sale proceeds). External commercial borrowing has been relaxed but is regulated with respect to maturities and interest rate spreads. As things stand today, inflows of most varieties have been fully liberalised. Outflows by corporate entities and banks have been considerably freed of controls. Only possible outflows by individuals are restricted. ${ }^{9}$

A salutary reminder is in order before moving on to discuss some of the macroeconomic challenges facing the Indian economy in detail. In spite of great strides that India has made in terms economic growth in the last decade and a half, in terms of employment it still remains primarily an agricultural economy, with the sector accounting for over sixty percent of employment and a fifth of its GDP. The services sector contributes to over 55 percent of GDP. Thus textbook monetary and fiscal policies, insofar as they are discussed in terms of investment, inventories etc., cater to only about a quarter of its GDP.

Returning to the burning issues, it is the case that apart from the restrictive labour laws (the discussion of which will take us too far afield), the two areas where not much progress has been made are government finances and commercial banking. We shall see that these are interlinked. And we argue that given these problems, it is not a propitious time to liberalise the capital account any further.

(See Table 2)

Table 1 provides the figures on the non-performing assets (NPAs) of the commercial banks while Table 2 provides some data on public finance. The central and the provincial (state) governments continue to run large deficits-the combined fiscal deficit of the Centre and the states was 7.5 percent of GDP in the last two years down from ten percent four years back. ${ }^{10}$ The deficits now have to be financed with more deregulated market-determined interest rate--fortunately for the government, global interest rates have been low (even in the recent oil price rise period) and so are the domestic rates.

\footnotetext{
${ }^{7}$ The government-owned banks still continue to be in a pre-eminent position, accounting for over 80 percent of bank deposits and over 60 percent of all assets of the financial sector.

8 India signed Article VIII of IMF's Articles of Agreement in 1994.

${ }^{9}$ Restrictions on the flow of capital have used two broad types of control mechanisms: (a) which distinguishes between transactions-implemented e.g., in Chile, Argentina, and (b) which differentiates between domestic residents and others--the strategy followed in India and South Africa--with domestic residents being forbidden from participating in certain transactions. This almost inevitably this translates in liberalizing inflows first, and then outflows.

${ }^{10}$ As a measure of governments fiscal health, it is far from perfect e.g., because it includes privatisation proceeds as revenue rather than it being "below the line".
} 
The noteworthy feature of the recent deficits is the high interest paymentsalmost four percent of GDP currently, down almost one percent from its peak four years back--and the continuing revenue deficits. The government's capital formation continues to be low, implying that the deficits are due to current consumption rather than investment.

There is a Fiscal Responsibility and Budget Management Act (FRBMA) passed by the Parliament in August 2003. As amended in July 2004, it seeks to reduce the fiscal deficit of the Centre to 3 percent of GDP by 2008-09 and also to balance the revenue deficit. It also proposes annual reductions in these deficit measures. Buiter and Patel (2006) discuss these proposals at length but are not very sanguine about the prospects of these targets being achieved.

Kletzer (2004, p. 243) points out that the budget figures of the central and state governments give an incomplete account of the liabilities of the public sector. There are unfunded pension liabilities, various contingent liabilities and the government guaranteed debt issued by public enterprises. ${ }^{11}$ Inclusion of these liabilities increases the consolidated deficit by between 1.0 and 1.5 percent of GDP. There are other explicit debt guarantees e.g., borrowing through special purpose vehicles for irrigation projects, and lending by banks and other non-bank financial institutions under state guarantees. The total contingent guarantees of the state and central governments are estimated to amount to 11.5 percent of GDP for 2002-03.

In an economy where the government is a large borrower and owns a large part of the banking system, to expect these banks to respond to commercial consideration over those of its owners is to expect too much. So while there has been a very dramatic reduction in the CRR, the SLR continues to be 25 per cent. It is also true that while the fiscal situation has a bearing on the health of the banks, the possible failure of banks (even privately-owned ones) could have an equally important effect on the fiscal deficit. This would work through deposit insurance and/or a "too big to fail" policy. ${ }^{12}$ It has been stressed by many commentators ${ }^{13}$ that government ownership of banks gives rise to regulatory forbearance and anticipating this, the banks make no attempts at hedging risks--the participants see no downside risk even if insolvency is possible. ${ }^{14}$ Buiter and Patel (2006) note that the problem of information asymmetry is aggravated that increases, rather than lowering, financial fragility.

Therefore, the government-owned banks continue to behave in an oligopolistic manner. There are floors on short-term deposits (and the banking

\footnotetext{
${ }^{11}$ The largest of these are losses of the State Electricity Boards.

12 Regulatory forbearance and state ownership of the banking sector implies hidden contingent liabilities for the public sector.

${ }_{13}$ See e.g., Joshi and Little (1994), Sen (2001), Kletzer (2004), Buiter and Patel (2006)

${ }^{14} \mathrm{It}$ is interesting to note however that following the collapse of a private bank, the depositors were compensated but not the owners.
} 
sector constitutes well over sixty per cent of the financial sector) and high administered rates on certain categories of deposits (e.g., small saving instruments). On the lending side there are still guidelines for the priority sectors, including small scale industry. Projects under implementation are still not classified as NPAs even if interest and repayments are six months overdue.

As an example of regulatory forbearance take the recent rise in interest rates following the increase in the price of (imported) oil. Government securities held by banks whose market value would have taken a hit were reclassified as held to maturity! This, when the same banks had made huge profits on their treasury operations in the years immediately preceding, when interest rates were low. In those years SLR eligible securities constituted as much as 45 percent of their assets ( 25 percent being the minimum requirement). In a commercial environment if the banks were holding fixed-interest-rate public debt, they should have hedged against interest rate fluctuations by either issuing deposit liabilities with inflexible interest rates or by trading in interestbased derivatives.

Protestations to the contrary notwithstanding, the public assume rationally that in the event of trouble the government would bail out the financial sector. Hence regulation is essential to ensure that a crisis when it occurs is not magnified by a large number of these off-budget liabilities that become onbudget. If this were to happen, especially with an open capital account, agents would assume (and these would be self-fulfilling) that the (current and future) budget deficits would be monetised.

Thus the presence of capital controls enables the government to pre-empt domestic savings for funding its deficits. India's external debt-to-GDP ratio was 15.8 percent in 2006, 31.5 percent of which consisted of borrowing on concessional terms (and only 7 percent of the external debt was short term). Thus most of the public debt was held internally.

Capital controls then ensures that the government does not have to resort to monetisation. Opening the capital account would raise the cost of borrowing for the government since preemption of domestic financial savings would now not be possible. This would put further pressure on government finances. Thus "India's increasing public debt-to-GDP ratio must eventually lead either to fiscal reform to close the fiscal gap, or to monetization of public sector budget deficits, or a combination of the two. Liberalization of international financial transactions will raise pressure for inflationary monetary growth and make the need for fiscal reform more urgent." (Kletzer (2004) p. 249).

Buiter and Patel (2006) (p. 28) sum up the situation thus: “...the combination of fiscal excess.....with financial repression and distortions in the formal financial system and with poor investment choices by publicly-owned financial institutions weakens the quantity and quality of private investment and this retards growth." 
To conclude, then, in a scenario such as the one painted above, there are three reasons why capital account convertibility may not be a good idea--later on we will look at the macroeconomic development strategy and pose further questions about the desirability of opening up capital accounts in emerging economies. The first two are those discussed above viz. the government's fiscal deficits and the public debt, and the weakness of the financial sector cast doubts on the ability of the economy to handle inflows. The third reason is the ability of this sector to handle outflows as these are liberalised. Outflows will take away the captive domestic financial market used to preempt financial resources to meet the government needs. The budget deficit could then be transformed into a current account deficit and, accompanying the expectations of monetisation, possibly cause a large depreciation. Thus the attraction of a liberalised capital account recedes when we take into account the heavy distortions implied by the history of financial repression.

\section{Capital Flows and Monetary Policy in the last decade and a half}

In this section I look at the details-somewhat uncritically, saving the contentious issues for the next section--of the Indian monetary policy, with the constraints imposed by a more open capital account, since the start of liberalisation. As mentioned in the preceding section, international trade was freed of a lot of controls since the process of liberalisation began. The rupee is now convertible on the current account. Capital inflows (except for shortterm debt) have been liberalised-these have seen the removal of quantitative restrictions and increasing the size of flows that are automatically approved. There are no bars to the repatriation, both the principal and returns, on these inflows. Outflows have been liberalised for banks and industry but still remain illiberal for individuals. ${ }^{15}$

\section{(See Table 3)}

Table 3 shows the evolution of various indexes of exchange rate since 199394. As the first column shows, in nominal terms the rupee has depreciated steadily against the US\$ (by over fifty per cent by 2002-03, before appreciating by about 8 per cent over the next three years). The second column shows that the depreciation was much less against a broad aggregate of currencies (a fall in the index denotes a depreciation of the rupee). The final column reveals the interesting fact that rupee in real terms has not moved much against a 36 currency export-weighted basket. There are periods of appreciation (in the first five years since 1993-94, followed by some real depreciation, but finally ending with a real appreciation. Thus the nominal depreciation more or less exactly offset inflation differentials between India and its trading partners over this period.

Lest one jumps to the conclusion that purchasing power parity holds between India and its trading partners, it has to be pointed out that the nominal

\footnotetext{
15 A distinction is made between Indians resident in India and the non-resident Indians (NRIs). See Joshi and Sanyal (2004) and Sen (2002) for details.
} 
exchange rate was managed by the $\mathrm{RBI}$ through regular intervention. This took the form of a sterilised intervention. The RBI bought foreign currency and then reversed the increase in high-powered money by selling government securities. Because of pervasive capital controls, the RBI was able to perform sterilisation. ${ }^{16}$ This policy, while immensely successful to date in insulating the real exchange rate and the economy from capital flows, is not without costs. Effectively, the $\mathrm{RBI}$ is exchanging low return foreign exchange holdings for high interest government bonds-this is the quasi-fiscal costs of sterilisation. This policy would become untenable as the RBI continues to accumulate foreign exchange reserves and thus driving up interest rates

Through sterilization the RBI was able to prevent a "Dutch Disease" type of a situation from occurring. The "Dutch Disease" refers to a scenario where the inflow of financial capital causes a real appreciation and squeezes the traded goods sector. ${ }^{17}$

(See Table 4)

Table 4 shows the sources of high-powered money growth. The foreign assets of the reserve bank grew faster than reserve money in all the years barring four since 1993-94. Since 2004 the RBI's holding of foreign exchange has exceeded reserve money (i.e., its holding of government debt is negative). ${ }^{18}$ The $\mathrm{RBI}$ now holds more than adequate foreign exchange reserves for normal contingencies ${ }^{19}$--in October of 2006, the reserves stood at US \$ 166.2.billion. Between 2002 and 2004 these reserves covered over one year of imports, falling to about ten months in 2005 . Thus the social benefit to additional reserve holdings are low (possibly negative), and the costs high. The best-case scenario, from the perspective of the Indian policy-makers, would be a (slow) capital outflow from India. This, of course, is beyond the control of the authorities and depends on the world economy. Having mounted the tiger of excessive capital inflows willingly, it seems the only way to dismount is to pray for the tiger to die.

(See Table 5)

Table 5 shows that the current account of India's balance of payments has been in deficit for most of the last decade and a half, but the deficit has been of a very manageable proportion. Thus India's foreign indebtedness is not growing $^{20}$, or at least not at a rate that is cause for alarm (the growth is certainly slower than population growth or even the real interest rate). The trade deficit is quite large-it was 6.5 percent of GDP last financial year--but invisibles help close the gap. It is worth pointing out that remittances are greater than the (much-hyped) software service receipts since the beginning of this decade.

\footnotetext{
16 With a fully open capital account, the domestic interest rate for a small open economy would be given by the foreign one. Sterilisation becomes impossible in such a scenario.

${ }^{17}$ This is true of all capital flows insofar as they lead to added demand for non-traded goods.

18 Joshi and Sanyal (2004) discuss this at length.

19 In a crisis, as in a bank run, only 100 per cent reserves would be adequate!

${ }^{20}$ The current account deficit changes a country's claims against the rest of the world.
} 
Thus whatever macroeconomic action there has been must be in the capital account. The capital account surplus has been large. As Table 5 shows it has been less than 2 per cent of GDP only in three years since 1993-94, and in 2004-05 it was 4.5 per cent of GDP. FDI seems to have peaked in 1997-98 at 3.5 per cent of GDP and has fallen back to well under one per cent of GDP. ${ }^{21}$ Portfolio investment flows, having been very strong around the middle of the nineties, have also fallen but not as much as FDI. It is to offset this capital account surplus (and to prevent "Dutch Disease") that the RBI has been accumulating foreign exchange reserves, thereby preventing an appreciation of the rupee.

To sum up the recent Indian experience with the external sector: the sizeable capital inflows (FDI and FII) would have caused a nominal and real appreciation, and the RBI has thwarted this by intervening in the foreign exchange market and buying foreign exchange. It has then sterilised the money supply by selling bonds. The effect of this is to increase the interest rate on domestic assets and, thereby, gives rise to a "quasi-fiscal" cost. ${ }^{22}$ Absent these capital flows, there would be real depreciation that could allow the economy to run a trade (and current account) surplus.

Non-FDI-capital flows are primarily flows from foreign institutional investors (FIIs) and are restricted to listed securities in the stock exchange. Their effect on the real economy would presumably work through a Tobin's " $q$ ". ${ }^{23}$ Following a rise in share prices, firms would increase investment by issuing new shares. It is interesting in this context to note that in the last 25 years, new issues by non-government firms have exceeded one percent of GDP only in five years. ${ }^{24}$ These were all in the early 1990s. So the inflows do not seem to be working through a "q" type of a mechanism.

\section{The Capital Account Convertibility Debate and India}

In this section, I shall deal with the literature on capital account convertibility in emerging markets. I shall first deal with the issue in an otherwise maximising neoclassical framework and examine the effects of financial underdevelopment, fiscal profligacy and contagion-i.e., allowing for developing country characteristics. Then I shall revert to an economy where aggregate demand could be a problem and identify how openness might overcome these. This is more speculative, since growth strategies are usually examined in a model where supply, not demand, is the constraint.

\footnotetext{
${ }^{21}$ The RBI and World Bank figures give different figures for the FDI/GDP ratio. In the latter series the peak is later (in 2002).

22 The rise in domestic interest rate may generate further flows but probably have a dampening effect on stock prices.

${ }^{23}$ See the Lahiri Committee (Government of India (2005), paragraph 40).

${ }^{24}$ See RBI (2006), Table 81 for figures.
} 
Twenty years back Carlos Diaz-Alejandro wrote a paper with an apocalyptic title "Good-bye Financial Repression, Hello Financial Crash". This has been the fate that has befallen many a developing country that has tried to open up its capital account "prematurely". Recent examples are Mexico in 1994, the Asian crisis of 1997 and the 1998 crisis in Latin America. What are the lessons that one learns from this experience?

I will present the arguments for free mobility of capital in brief, since this is well-known territory. It is argued that free trade in assets, like free trade in goods, would raise welfare (in a neoclassical setting i.e., without problems of information asymmetry, distortions etc.), since it allows risk diversification and consumption-smoothing opportunities. In particular, financial integration would allow agents in a developing economy to borrow in anticipation of future income (consumption-smoothing) and also borrow capital to be used in production to raise incomes (consumption-augmenting). Surely, free trade expands the opportunity set and, therefore, cannot be welfare-reducing? And why not open up the markets immediately, since doing so slowly would be sheltering inefficiency? Proponents go on to argue that where no markets existed new ones would emerge e.g., for hedging foreign exchange risk, government securities.

As developing economies embraced this idea and opened up their capital accounts to international flows, they soon found out that asset markets are different from goods markets and developing country markets different from those in developed ones. ${ }^{25}$ The initial Latin American crises pointed to a lack of macroeconomic balance - budget deficits turned into current account deficits and a crisis followed. The literature that emerged suggested a sequencing of liberalisation rather than a "big bang" one. In the light of the East Asian experience, inadequate regulation and supervision of the financial sector including the government guaranteeing the liabilities of the banking system have been added to the list.

For instance, a recently-liberalised economy with inadequate prudential regulation is confronted with an increase in the volatility of bank deposits. This could be source of a crisis. Banks have liabilities that are short term and assets that are long term. This necessitates the management of maturity risk, and banking regulation has to ensure that this risk is hedged.

Thus, we require well-functioning goods and financial markets to benefit from capital inflows, well-functioning meaning both having depth and well-regulated (and transparent). A movement away from quantitative restrictions to more market determined interest rates, prudential norms ${ }^{26}$, development of a money market, a market for government securities, a foreign exchange

\footnotetext{
${ }^{25}$ The Southern Cone (Chile, Argentina and Uruguay) liberalisation in the early 1980s was the first of these.

${ }_{26}$ E.g., the Basle prudential norms set some internationally comparable standards in the banking sector.
} 
market, the existence of a yield curve for pricing floating rate instruments etc., are required to be in place.

Absent these, what seems to be a welfare-improving activity in isolation could interact with some other feature of an underdeveloped market that acts as a distortion. Needless to say a developing economy's financial market lacks depth and the experience to date on this seems to suggest that acquiring these attributes can be speeded up only so much. ${ }^{27}$

Does the liberalisation of the capital account make the economy more or less vulnerable to financial crisis? More generally what are the costs and benefits of such liberalisation? An economy with an unsustainable fiscal policy may find that it is unable to borrow following an opening up of outflows -or the terms on which it borrows become very unfavourable-- as capital flows out. This then leads to an expectation of monetisation of the deficits causing a rapid currency depreciation that, in turn, causes a financial crisis. If the exchange rate is fixed then this expectation of a future monetisation could cause the peg to collapse and a large depletion of foreign exchange reserves.

A "surprise" inflation, of course, benefits the government qua borrower in that it reduces the real value of the debt. This, however, is not true of an economy like India where most debt is held by the financial institutions owned by the government.

Kletzer (2004, p. 235) points out another problem: “...maturity mismatch also arises for other types of international capital flows to developing countries. Lending at short maturities arises endogenously in simple theoretical models in the presence of investment gestation lags. With such lags, a reversal of short-term lending can lead to a liquidity crisis even if the country could repay its debt in full if the reversal had not occurred. In such cases long-maturity loans are welfare improving, but short-maturity lending allows creditors to exit before the country is forced to restructure its debt. With short-term debt in the market, long-maturity debt becomes risky, and lenders can demand a large risk premium, leading debtors to borrow at short maturities."

In the policy circles, therefore, FDI is viewed more favourably since it gives rise to equity claims getting around the maturity mismatch and the currency mismatch problems, in addition to the benefits it bestows in the form of technology transfer (that raises productivity).

The above catalogue of prerequisites, that are required to be in place before opening up the capital account, pertain to the domestic economy getting its act together. And the analysis is partial equilibrium in nature (i.e., it is very specific sector-oriented).

\footnotetext{
${ }^{27}$ See Caballero and Krishnamurthy (2001) who, for instance, model a developing economy as having two constraints-one for domestic assets and the other for foreign ones. A developed economy has only an aggregate constraint on borrowing.
} 
I now turn to the macro aspects of capital flows i.e., smoothing and augmenting of consumption by borrowing and lending. Consumptionsmoothing allows income fluctuations to be smoothed out, at least in theory. ${ }^{28}$ And capital outflows can help diversify risk. Against this we have a capital account shock-such as a sudden rise in the world interest rates or the complete drying up of capital flows (a "sudden stop")—that introduces a lot of volatility to consumption and investment, since the current account now needs to be (more) balanced. ${ }^{29}$ Also these shocks could be unrelated to the borrower's economic behaviour i.e., it could be due to "contagion".

What has been the recent macroeconomic experience with capital flows in developing economies? Have these supplemented domestic savings and put the recipients on higher growth trajectory? And have these flows allowed economies to smooth and augment consumption?

In the year following the devaluation of the Thai currency in July 1997, capital flows to the five Asian countries, i.e., Indonesia, Korea, Malaysia, Philippines and Thailand, fell from US\$ 47 billion (or 4.3 percent of GDP) to minus US\$ 58 billion (or -5.5 percent of GDP). ${ }^{30}$ In the second half of the 1990 s bank lending to the Asian economies was very volatile, whereas for Latin America it was portfolio flows that showed a higher volatility.

There was a debate among macroeconomists some year back as to whether capital flows to emerging markets are caused by "push" (i.e., causes in lender countries) or "pull" (i.e., the environment in the borrowing countries) factors. Calvo and Talvi (2006) point out that in the seven major Latin American countries (their LAC-7) capital flows increased from minus US\$13 billion to US\$ 100 billion (constituting 5.5 percent of GDP) between the years ending in the fourth quarter of 1989 and the second quarter of 1998. Therefore they conclude, "The highly synchronized and widespread increase in capital inflows to a variety of very diverse countries suggests that the root cause of this bonanza must lie in a common external factors i.e., developments in central rather than peripheral countries." (p.7)

On the causes and consequences of the recent reversals in capital flows, it is worth quoting Calvo and Talvi ((2006) pp. 8-9) at length. They say: "Russia's default in August 1998...represented a fatal blow for Latin America...In tandem with the rest of emerging markets, interest rate spreads for LAC-7 rose from 450 basis points prior to the Russian crisis to 1,600 basis points in September 1998, more than tripling the cost of external financing in a period of weeks. As a result, capital inflows to LAC-7 countries came to a Sudden Stop, falling from 100 billion dollars (or 5.5 percent of GPD) in the year ending in II-1998 prior to the Russian crisis, to 37 billion dollars (or 1.9 percent of GDP) one year later...(N)on-FDI flows...fell by 80 billion dollars during that

\footnotetext{
${ }^{28}$ See Caballero (2000) for how in Chile's case, most macroeconomic series follow the international price of copper, it's main export. This, in spite of Chile being a market-oriented economy with fairly good regulatory institutions in place. See also his discussion on the volatility of the various stock-market indices in Argentina.

${ }^{29}$ See the discussion on the recent Latin American crisis below.

${ }^{30}$ See Williamson (2001) and Schneider (2001).
} 
period. After the initial blow, capital flows to LAC-7 suffered an additional blow after the Argentine crisis in 2001... and, later, the ENRON scandal...By the year ending in IV-2002 capital flows to LAC-7 were less than 10 billion dollars, back to the very low levels of the late 1980s. The Russian virus affected every major country in Latin America, with the exception of Mexico... Even Chile, a country with very solid economic fundamentals-a track record of sound macroeconomic management, a highly praised and sustained process of structural and institutional reforms that completely transformed and modernized Chile's economy, and an average rate of growth of 7.4 percent per year between 1985 and 1997, the highest growth rate in LAC-7-and tight controls on the inflows of foreign capital, experienced a sudden and severe interruption in capital inflows. In fact, the Sudden Stop in Chile in the year following the Russian crisis was 7.9 percent of GDP, the largest in LAC-7. That a partial debt default in Russia, a country that represented less than 1 percent of world GDP and had no meaningful financial or trading ties with Latin America, could precipitate a financial contagion shock wave of such proportions, posed a puzzle for the profession." ${ }^{31}$

Further they point out that in response to this shock to capital account-"by definition undesirable if not impossible to smooth"-- most of the adjustment in LAC-7 came not from additional savings but from reduced investment, which fell from 23 percent of GDP in 1997, prior to the Russian crisis, to 18 percent of GDP in 2002 (Calvo and Talvi (2006) p. 15)

With this quick tour of the recent experience of developing countries, I turn to the lessons for India from this experience. I begin by recalling from the Introduction that the quality of debate (such as it is) is very poor. ${ }^{32}$ This reflects the lack of a macroeconomic tradition in India, unlike Latin Americaof course, such a tradition is neither necessary nor sufficient to prevent a crisis. Also, neither the Finance Ministry nor the RBI have a macroeconomic model (not, at least, in the public domain) that is used for policy.

There is, however, a view that is very popular in the policy circles in India, and it gives a clue about how some influential people think about these matters. It is as follows: For a higher growth rate the rate of investment needs to be increased. One way to achieve this is to reinforce domestic savings with capital inflows by running a current account deficit. This is unexceptionable insofar as one is financing investment through FDI-if this goes into acquiring an existing firm, it does not count as investment. But what about portfolio investment? The logic is not clear here and the trail of explanation goes cold very quickly. Here is a quote from the report of a 1996 committee headed by Rakesh Mohan, currently Deputy Governor, RBI: "The sustainability of ...economic growth would require continuing high growth in exports, perhaps declining from the current 20 per cent annual growth to about 10 per cent by the end of the next decade, giving an average of about 15 per cent annual

31 In the Lahiri Committee Report (Government of India (2005)), this episode does not find a mention in the section 3.V titled "Episodes of Vulnerability" (sic), whereas the Soros' attack on sterling does.

32 See the references to Tarapore Committee II (RBI (2006)) and Lahiri Committee (Government of India (2005) elsewhere in this paper. 
growth over the period. If this takes place, total exports should reach about $\$ 66$ billion in $2000-01$ and $\$ 115$ billion by $2005-06$. At these levels, exports would comprise about 15 per cent of GDP in 2000-01 and 17 per cent of GDP by $2005-06$, up from the current levels of about 10 per cent. If exports manage to increase to these levels, it would become feasible for India to sustain a wider current account deficit which is required for the non-inflationary absorption of external capital inflows. It is suggested that a sustainable level of current account deficit would increase from the current level of 1.5 per cent of GDP to 2.5 per cent in 2000-01 and 3 per cent in 2005-06. It would then be possible for the net capital inflow to rise from the current level of about $\$ 7$ billion to $\$ 8$ billion to about $\$ 17$ billion to $\$ 20$ billion by $2000-01$ and about $\$ 25$ billion to $\$ 30$ billion by $2005-06 . " 33$

It seems that he would have a 3 percent current account deficit, so that capital inflows can "be absorbed". What would happen if there is an unanticipated increase in the price of oil or drying up of flows (as in the LAC-7 case discussed above)? I, for one, am having some difficulty here in telling the cart and the horse apart!

This is a hand-me-down version of the atavistic "stages-of-balance of payments" theory in which a poor country borrowed to grow and a rich country was a creditor. We have known for about thirty years that this does not necessarily happen in an optimising framework. And it is certainly not true empirically-just look at China and the US.

This leads me into speculating as to which "open" economy path is the appropriate one for India-especially if demand is a constraint. East and South-east Asian economies grew their way out of poverty by maintaining an undervalued exchange rate.

Economic theory is quite silent on this issue. International trade models with microeconomic underpinnings typically assume balanced trade and thereby emphasise comparative advantage alone (as opposed to exchange rate policies etc. that are seen to be part of an absolute advantage package). When a dynamic model is proposed, borrowing and lending is allowed but in a full-employment supply-constrained model (either with infinitely-lived agents, or with overlapping generations of agents with finite lives). This is true of models where growth is driven by exogenous factors or endogenous growth models. Demand is never a problem in these models and an undervalued

\footnotetext{
33 That the distinction between FDI and FIl flows from a macroeconomic management is not appreciated in Indian policy circles can also be seen in the Tarapore Committee II Report (see RBI (2006), paragraph 2.8). The Lahiri Committee has the following to say on this: "Foreign investment - both portfolio and direct varieties - can supplement domestic savings and augment domestic investment without increasing the foreign debt of the country. Such investment constitutes non-debt creating financing instruments for the current account deficits in the external balance of payments."(Government of India (2005) paragraph 40).
} 
exchange rate makes no sense. ${ }^{34}$ In a scenario with deficient aggregate demand, portfolio flows cause a real appreciation putting pressure on exports (the Dutch disease discussed above). It also causes a stock market boom that is excessive because this market is also thin. Moreover, it does nothing to alleviate the credit constraints of the firms which need it, since these are very unlikely to be listed (in the stock exchange) firms. ${ }^{35,}$,

As mentioned earlier, the experience of the East and South-east Asian economies does not fit into the typical neoclassical theoretical mould. While there are differences among this class of countries e.g., some like, China used FDI, while others, like Korea and Japan did not, all these economies had one point in common viz. they kept a tight lid on financial capital flows in the early stages of development. It is ironic that when capital mobility was allowed, ${ }^{37}$ their weak financial systems could not cope, and the Asian crisis resulted. At the other end of the spectrum is Latin America with its open capital account fairly early on its development path. Here while growth has taken place, these countries have also lurched from one crisis to another. Both growth and the crises have one common proximate cause-capital flows. $^{38}$ Since capital flow reversals take place independent of the fundamentals of the country (as do inflows), there is very little that any country can do to stop these reversals. ${ }^{39}$

If there are imperfections in the credit markets, borrowing from abroad typically involves sovereign risk. One can be sure that these risks are greater than lending to domestic firms (because of a common legal authority etc. for the latter kind of lending etc.). Thus a growth strategy that involves generating higher saving (backed by a relatively closed capital account) can make funds available for lending domestically on better terms than borrowing abroad. ${ }^{40}$

\footnotetext{
${ }^{34}$ I emphasize the distinction between an open (to financial flows) capital account and a closed one rather than a demand constrained versus a supply constrained setting. The latter distinction while crucial in the short run becomes blurred over time-e.g., investment creates demand in the short-run but augments supply in the next period.

35 In any case, as mentioned earlier, we do not see much action in the Indian data that points to private primary issues having received a shot in the arm when the stock market was booming.

${ }^{36}$ In the earlier version of this paper, in an Appendix a Keynesian-type model was sketched out-this was deleted because to integrate that analysis with the rest of the paper would have made this paper very long. The semi-reduced form of that model is estimated in my paper with P.Dua (2006).

37 Malaysia and Thailand, for example, had an open capital account for decades prior to the Asian crisis. But they received no inflows so there was no problem.

${ }^{38}$ See Caballero (2000) for examples casting doubts on the ability of inflows to generate positive effects.

${ }^{39}$ But as Calvo and Talvi (2006) point out, a country's economic structure and policies can determine how hard it is hit when a reversal takes place. They show that the Chilean meltdown was much more severe than in Argentina. Thus Chile was hit harder in the crisis than Argentina, but since recovery requires a country to run current account surpluses, this was something that Chile--being more open to trade--was able to do at a lower cost than Argentina.

40 Against this there is some evidence elsewhere in developing world, where lending was undertaken indiscriminately e.g., with consumption growth in Chile growing at over 40 per
} 
To sum up, as a growth strategy, the almost mercantilist East and South-east Asia is a preferred one over the open capital account Latin America. ${ }^{41}$ The strategy is outward-oriented and thus receives benefits that a trade-oriented regime bestows. By running a current account surplus, it generates aggregate demand and possible funds for investment. ${ }^{42} \mathrm{~A}$ trade balance surplus using the abundant labour for exports has a direct effect on poverty reduction.

The Indian experience since the capital account was thrown open to inflows suggests that while growth has accelerated and investment picked up somewhat, the continuing trade deficit due to the absence of real depreciation is a drag on the growth of income. ${ }^{43}$ Also the capital flows themselves do not seem to have resulted in an investment boom (via a Tobin's ' $q$ '). In any case, there is no evidence that capital flows have reduced credit constraints for the firms that were denied access to credit markets-i.e., there is "cherry picking" by the foreign lenders.

It goes without saying, that to pursue export-led growth strategy, supply bottlenecks will have to be removed. Unlike China, levels of literacy in India are quite low, physical infrastructure-in roads, railways, ports etc-needs overhaul. Labour market rigidities and regulations that work against the realisation of scale economies will need to be removed. Without these, an increase in aggregate demand will feed through mainly into prices. On the other hand, it is also true that since liberalisation India's tradeable sector has shown remarkable resilience in overcoming some of these obstacles.

\section{Conclusions}

The Indian economy has come a long way since it shed controls (both domestic and international) at beginning of the 1990s. Its growth rate has been very robust, inflation low, and the external sector healthy. Its resilience has silenced many a doubting Thomas. But that is not the same as saying that we are out of the woods. There are areas of weakness (in a macroeconomic context, that is) that have to be addressed. In particular the fiscal and banking problems are serious. In a setting such as this, rushing into embracing capital account convertibility could prove fatal.

\footnotetext{
cent (surely a harbinger of trouble) before the crisis in the early 1980s. Similarly, in the muchquoted example of a currency-mismatch where a taxi-cab company in Indonesia borrowed huge amounts in US dollars. These episodes of indiscriminate lending were a good predictor of crises, rather than sustained growth.

41 In a supply constrained full-employment set-up keeping one's real exchange rate undervalued is inflicting a terms of trade deterioration on oneself. Clearly it does not make sense in such a framework.

42 In a typical short-run macroeconomic models and in growth models (e.g., the decentralised version of the Ramsey model), saving and investment are done by different agents and equality between these is brought together by price and /or quantitity adjustments. In models with credit constraints, investment depends on net worth (and in simpler versions on savings)-see e.g., Obstfeld and Rgoff (1996) Chapter 6.

${ }^{43}$ The real appreciation does help the import of capital goods, which raises productivity. But capital goods import was part of an ongoing process of liberalisation that started in the 1980s, and hence did not require the real appreciation to jump-start it.
} 


\section{REFERENCES}

Broner, F. A. and R. Rigobon (2004), "Why are Capital Flows So Much More Volatile in Emerging than in Developed Countries?" University of Pompeu Fabra.

Buiter, W.H. and U.R. Patel (2006), "Excessive Budget Deficits, A Government-Abused Financial System and Fiscal Rules", India Policy Forum 2, 1-38.

Caballero, R. (2000), "Macroeconomic Volatility in Latin America: A View and Three Case Studies", Economia 1, 31-108.

Caballero, R. and A. Krishnamurthy (2001) International and Domestic Collateral Constraints in a Model of Emerging Market Crises, Journal of Monetary Economics 48(3), December 2001, 513-548

Calvo, G. A. and E. Talvi (2006), "Sudden Stop, Financial Factors and Argentina and Chile", National Bureau of Economic Research, Working Paper No. 11153.

Dua, P. and P. Sen (2006), "Capital Flows, Volatility and Exchange Rates:

The Case of India" Centre for Development Economics Working Paper 144. Government of India (1991), "Report of the Committee on the Financial System" (Chairman M.Narsimham), Ministry of Finance, New Delhi. Government of India (1996), "The India Infrastructure Report" (Chairman: R. Mohan), Ministry of Finance.

Government of India (2005), "Report of the Expert Group on Encouraging FII Flows and Checking the Vulnerability of Capital Markets to Speculative Flows" (Chairman A. Lahiri), Ministry of Finance, New Delhi.

Joshi, V. and I.M.D. Little (1994) India: Macroeconomics and Political Economy (Oxford, New Delhi, India).

Joshi, V. and S. Sanyal (2004), "Foreign Inflows and Macroeconomic Policy in India", India Policy Forum 1, 135-179.

Kletzer, K. (2004), "Liberalizing Capital Flows in India: Financial Repression", Macroeconomic Policy and Gradual Reform", India Policy Forum 1, 227-263. Mishkin, Frederic S. (2004) "Can Inflation Targeting Work in Emerging Market Countries?", National Bureau of Economic Research, Working Paper No. 10646. 
Obstfeld, M. and K. Rogoff (1996) "Foundations of International Macroeconomics" MIT Press (Cambridge MA).

Reserve Bank of India (1985) Report of the Committee to Review the Working of the Monetary System (Chairman S. Chakravarty)

Reserve Bank of India (2006) Report of the Committee on Fuller Capital Account Convertibility (Chairman: S.S. Tarapore)

Reserve Bank of India (1985) Report of the Committee to Review the Working of the Monetary System (Chairman S. Chakravarty).

Reserve Bank of India (2006) Handbook of Statistics on Indian Economy

Schneider, B. (2001), "Issues in Capital Account Convertibility in Developing Countries", Development Policy Review 19, 31-82.

Sen, P. (2001), "India's Financial Sector Reforms: Progress and the Macroeconomic Constraints", in M. Tsurumi (ed) Financial Big Bang in Asia (Ashgate, Aldershot, UK)

Sen, P. (2002), "The Exchange Rate Since Liberalization and Issues in Capital Account Convertibility" in Raghabendra Jha (ed) Ten years of Indian Reforms (ANU Press, Canberra).

Williamson, J. (2001), "Issues Regarding the Composition of Capital Flows", Development Policy Review 19, 11-29. 
All Tables are from the RBI website: www.rbi.org.in

Table 1

Major Macroeconomic Indicators (\% changes)

\begin{tabular}{|c|c|c|c|c|c|}
\hline Fiscal Year & $\begin{array}{c}\text { Aggregate } \\
\text { GDP }\end{array}$ & $\begin{array}{c}\text { Broad } \\
\text { Money }\end{array}$ & $\begin{array}{c}\text { Whole-sale } \\
\text { Price Index }\end{array}$ & $\begin{array}{c}\text { Non- } \\
\text { Performing } \\
\text { Assets * }\end{array}$ & $\begin{array}{c}\text { Current } \\
\text { Account } \\
\text { Bal (\% of GDP) }\end{array}$ \\
\hline $1990-91$ & 5.6 & 15.1 & 10.3 & & -3.1 \\
\hline $1991-92$ & 1.3 & 19.3 & 13.7 & & -0.3 \\
\hline $1992-93$ & 5.1 & 14.8 & 10.1 & & -1.7 \\
\hline $1993-94$ & 5.9 & 18.4 & 8.4 & & -0.4 \\
\hline $1994-95$ & 7.3 & 22.4 & 12.5 & & -1.0 \\
\hline $1995-96$ & 7.3 & 13.6 & 8.1 & 7.0 & -1.7 \\
\hline $1996-97$ & 7.8 & 16.2 & 4.6 & 6.4 & -1.2 \\
\hline $1997-98$ & 4.8 & 18.0 & 4.4 & 6.2 & -1.4 \\
\hline $1998-99$ & 6.6 & 19.4 & 5.9 & 5.5 & -1.0 \\
\hline $1999-00$ & 6.4 & 13.9 & 3.3 & 4.9 & -1.0 \\
\hline $2000-01$ & 5.2 & 16.2 & 7.0 & 4.6 & -0.6 \\
\hline $2001-02$ & 5.6 & 14.2 & 3.6 & 4.0 & 0.7 \\
\hline $2002-03$ & 4.3 & 12.8 & 3.4 & 3.3 & 1.3 \\
\hline $2003-04$ & 8.5 & 16.4 & 5.4 & 2.6 & 2.3 \\
\hline $2004-05$ & 7.5 & 12.3 & 6.5 & 2.5 & -0.8 \\
\hline $2005-06$ & 8.4 & 21.2 & 4.4 & & -1.3 \\
\hline
\end{tabular}

*NPAs as percentage of assets of commercial banks 
Table 2

Some Fiscal Indicators

\begin{tabular}{|c|c|c|c|}
\hline Year & $\begin{array}{c}\text { Gross Fiscal } \\
\text { Deficit (C+S) }\end{array}$ & $\begin{array}{c}\text { Revenue } \\
\text { Deficit (C+S) }\end{array}$ & $\begin{array}{c}\text { Interest } \\
\text { Payments (C) }\end{array}$ \\
\hline $\begin{array}{c}\text { Annual Average } \\
\text { 1990-91 to1994-95 }\end{array}$ & 7.8 & 3.7 & 4.1 \\
\hline $\begin{array}{c}\text { Annual Average } \\
\text { 1995- 96 to 1999-2000 }\end{array}$ & 7.8 & 4.7 & 4.4 \\
\hline 2000-01 & 9.6 & 6.6 & 4.8 \\
\hline $2001-02$ & 10.0 & 7.0 & 4.7 \\
\hline $2002-03$ & 9.5 & 6.6 & 4.8 \\
\hline $2003-04$ & 8.5 & 5.8 & 4.5 \\
\hline $2004-05$ & 7.6 & 3.7 & 4.1 \\
\hline $2005-06$ & 8.4 & 3.5 & 4.2 \\
\hline $2006-07$ & 7.3 & 2.5 & 4.0 \\
\hline
\end{tabular}

$\mathrm{C}=$ Centre, $\mathrm{S}=$ States 
Table 3

Exchange Rates of the Indian Rupee

\begin{tabular}{|c|c|c|c|c|}
\hline Fiscal Yr & Rs/US \$ & $\begin{array}{c}\text { Nominal } \\
\text { Effective } \\
\text { Exch. Rate* }\end{array}$ & $\begin{array}{c}\text { Real Effective } \\
\text { Exch. Rate** }\end{array}$ & $\begin{array}{c}\text { Foreign exchange } \\
\text { Reserves (US \$ bn) }\end{array}$ \\
\hline $1993-94$ & 31.4 & 100.0 & 100.0 & 19.3 \\
\hline $1994-95$ & 31.4 & 98.2 & 104.9 & 25.2 \\
\hline $1995-96$ & 33.5 & 90.9 & 100.1 & 21.7 \\
\hline $1996-97$ & 35.5 & 89.0 & 98.9 & 26.4 \\
\hline $1997-98$ & 37.2 & 92.0 & 103.0 & 29.4 \\
\hline $1998-99$ & 42.0 & 90.3 & 94.3 & 32.5 \\
\hline $1999-00$ & 43.3 & 90.4 & 95.3 & 38.0 \\
\hline $2000-01$ & 45.7 & 90.1 & 98.7 & 54.3 \\
\hline $2001-02$ & 45.7 & 89.1 & 98.6 & 76.1 \\
\hline $2002-03$ & 48.4 & 87.0 & 96.0 & 113.0 \\
\hline $2003-04$ & 45.6 & 87.9 & 99.1 & 141.5 \\
\hline $2004-05$ & 44.9 & 88.4 & 98.3 & 151.6 \\
\hline $2005-06$ & 44.3 & 91.2 & 100.8 & \\
\hline
\end{tabular}

* 36 Currency export based (base 1993-94=100)

** 36 Currency export based (base 1993-94 = 100) 
Table 4

Sources of Reserve Money Growth (Rs bn)

\begin{tabular}{|c|c|c|c|c|}
\hline & RMC & NFAC & NDAC & NDA/RM \\
\hline $\begin{array}{c}\text { Annual Average 1990- } \\
\text { 91 to 1994-95 }\end{array}$ & 183 & 137 & 46 & 74 \\
\hline $\begin{array}{c}\text { Annual Average 1995- } \\
\mathbf{9 6} \text { to 1999-2000 }\end{array}$ & 222 & 182 & 40 & 50 \\
\hline $2000-01$ & 227 & 313 & -86 & 35 \\
\hline $2001-02$ & 347 & 668 & -321 & 22 \\
\hline $2002-03$ & 309 & 942 & -633 & 3 \\
\hline $2003-04$ & 675 & 1262 & -588 & -11 \\
\hline $2004-05$ & 526 & 1284 & -758 & -25 \\
\hline $2005-06$ & 839 & 602 & 237 & -17 \\
\hline
\end{tabular}

RMC: Changes in reserve money

NFAC: Changes in net foreign exchange assets of RBI

NDAC: Changes in net domestic assets of RBI 
Table 5 Balance of Payments (\% of GDP at market prices)

\begin{tabular}{|c|c|c|c|c|c|c|c|c|c|c|c|c|c|c|c|c|}
\hline & $\begin{array}{c}1990- \\
91\end{array}$ & $\begin{array}{l}1991- \\
92\end{array}$ & $\begin{array}{c}1992- \\
93\end{array}$ & $\begin{array}{c}1993- \\
94\end{array}$ & $\begin{array}{c}1994- \\
95\end{array}$ & $\begin{array}{c}1995 \\
96\end{array}$ & $\begin{array}{c}1996- \\
97\end{array}$ & $\begin{array}{c}1997- \\
98\end{array}$ & $\begin{array}{c}1998- \\
99\end{array}$ & $\begin{array}{c}1999- \\
00\end{array}$ & $\begin{array}{c}2000- \\
01\end{array}$ & $\begin{array}{l}2001- \\
02\end{array}$ & $\begin{array}{c}2002 \\
03\end{array}$ & $\begin{array}{c}2003- \\
04\end{array}$ & $\begin{array}{c}2004 \\
05\end{array}$ & $\begin{array}{c}2005- \\
06\end{array}$ \\
\hline Exports f.o.b & 5.8 & 6.9 & 7.3 & 8.3 & 8.3 & 9.1 & 8.9 & 8.7 & 8.2 & 8.3 & 9.9 & 9.0 & 10.6 & 11.0 & 12.3 & 13.1 \\
\hline Imports c.i.f & 8.8 & 7.9 & 9.6 & 9.8 & 11.1 & 12.3 & 12.7 & 12.5 & 11.4 & 12.3 & 12.5 & 11.3 & 12.7 & 13.2 & 17.1 & 19.6 \\
\hline Trade Balance & -3 & -1 & -2.3 & -1.5 & -2.8 & -3.2 & -3.9 & -3.8 & -3.2 & -4 & -2.7 & -2.3 & -2.1 & -2.3 & -4.9 & -6.5 \\
\hline Net Invisibles & -0.1 & 0.7 & 0.6 & 1.1 & 1.8 & 1.6 & 2.7 & 2.4 & 2.2 & 2.9 & 2.1 & 3.0 & 3.4 & 4.6 & 4.5 & 5.1 \\
\hline $\begin{array}{c}\text { Total Current } \\
\text { Account }\end{array}$ & -3.1 & -0.3 & -1.7 & -0.4 & -1 & -1.7 & -1.2 & -1.4 & -1 & -1 & -0.6 & 0.7 & 1.3 & 2.3 & -0.8 & -1.3 \\
\hline $\begin{array}{l}\text { Capital Account } \\
\text { Surplus }\end{array}$ & 2.3 & 1.5 & 1.6 & 3.5 & 2.8 & 1.3 & 3 & 2.4 & 2 & 2.3 & 1.9 & 1.7 & 2.1 & 2.8 & 4.5 & 3.1 \\
\hline $\begin{array}{c}\text { Foreign } \\
\text { Investment }\end{array}$ & 0.1 & 0.1 & 0.3 & 1.6 & 1.5 & 1.4 & 1.6 & 1.3 & 0.6 & 1.2 & 1.3 & 1.3 & 0.8 & 2.3 & 1.9 & 2.3 \\
\hline Direct & 0.1 & 0.1 & 0.3 & 0.6 & 1 & 2 & 2.9 & 3.6 & 2.5 & 2.1 & 0.7 & 0.9 & 0.7 & 0.4 & 0.5 & 0.7 \\
\hline Portfolio & 0 & 0 & 0.3 & 3.6 & 3.8 & 2.8 & 3.3 & 1.8 & -0.1 & 3.1 & 0.6 & 0.4 & 0.2 & 1.9 & 1.3 & 1.6 \\
\hline $\begin{array}{c}\text { External } \\
\text { Assistance }\end{array}$ & 0.7 & 1.1 & 0.8 & 0.7 & 0.5 & 0.3 & 0.3 & 0.2 & 0.2 & 0.2 & 0.1 & 0.2 & -0.6 & -0.5 & 0.3 & 0.2 \\
\hline $\begin{array}{l}\text { Commercial } \\
\text { Borrowings }\end{array}$ & 0.7 & 0.6 & -0.2 & 0.2 & 0.3 & 0.4 & 0.7 & 1 & 1.1 & 0.1 & 0.9 & -0.3 & -0.3 & -0.5 & 0.7 & 0.2 \\
\hline NRI Deposits & & & & & & & & & & & 0.5 & 0.5 & 0.6 & 0.6 & -0.1 & 0.3 \\
\hline IMF net & 0.4 & 0.3 & 0.5 & 0.1 & -0.4 & -0.5 & -0.3 & -0.2 & -0.1 & -0.1 & 0.0 & 0.0 & 0.0 & 0.0 & 0.0 & 0.0 \\
\hline
\end{tabular}

